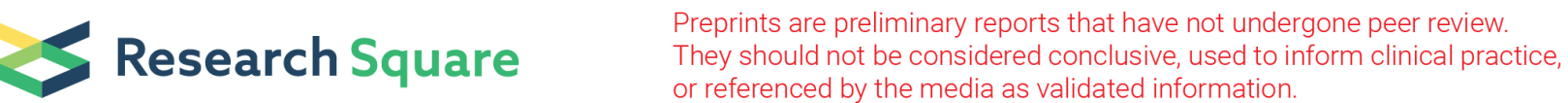

\section{A newly isolated Cerrena unicolor capable of laccase production and lignin degradation in agricultural wastes}

Jiahui Tian

Biology Institute, Qilu University of Technology (Shandong Academy of Sciences), Ji'nan 250103, Shandong, PR China

Jiali Feng

Biology Institute, Qilu University of Technology (Shandong Academy of Sciences), Ji'nan 250103, Shandong, PR China

\section{Ying Wang}

Biology Institute, Qilu University of Technology (Shandong Academy of Sciences), Ji'nan 250103, Shandong, PR China

\section{Junhua Lu}

Biology Institute, Qilu University of Technology (Shandong Academy of Sciences), Ji'nan 250103, Shandong, PR China

\section{Linjing Mao}

Biology Institute, Qilu University of Technology (Shandong Academy of Sciences), Ji'nan 250103, Shandong, PR China

Jie Chu ( $\square$ chujie6532@163.com )

Biology Institute, Qilu University of Technology (Shandong Academy of Sciences), Ji'nan 250103, Shandong, PR China

\section{Research Article}

Keywords: Cerrena unicolor, Laccase activity, Biodegradation, Agricultural wastes

Posted Date: December 10th, 2020

DOI: https://doi.org/10.21203/rs.3.rs-122812/v1

License: (c) (i) This work is licensed under a Creative Commons Attribution 4.0 International License. Read Full License 


\section{Abstract}

Lignin is main residue of agro-industrial biomass which can be decomposed through enzymatic hydrolysis by fungi. In this study, a strain was isolated from birch forest and identified as Cerrena unicolor GC.u01 by $18 \mathrm{~S}$ rDNA gene-sequencing technology. The activity of laccase (Lac) reached maximum $1605.28 \pm 32.21 \mathrm{U} \cdot \mathrm{L}-1$ at 8 th day via submerged fermentation, while the highest Lac activity by solid-state fermentation $1280.04 \pm 48.11 \mathrm{U} \cdot \mathrm{g}-1$ with rice stalks and $566.83 \pm 47.02 \mathrm{U} \cdot \mathrm{g}-1$ with wheat stalks were both obtained at 10th day, and $2677.50 \pm 49.38 \mathrm{U} \cdot \mathrm{g}-1$ with corn stalks at 12 th day. Then the lignin degradation ratios were up to $24.3 \%, 34.3 \%$ and $26.2 \%$ in wheat stalks, rice stalks and corn stalks, respectively, suggesting that the newly isolated Cerrena unicolor GC.u01 is potential for laccase production and lignin degradation by solid-state fermentation.

\section{Introduction}

Straw is mainly composed of cellulose, hemicellulose and lignin, which can be used as raw materials of high value-added products (Mathew et al. 2013; Mei et al. 2020). Cellulose and hemicellulose make up the entire biomass and are firmly linked to the lignin molecules via covalent and hydrogenic linkages, thus pretreatments must be performed to break down the compact structure into simple organic compounds primarily for the efficient utilization of straw, where the degradation of lignin is the key obstacle. Amount of studies have proved that pretreatment works for deconstructing the lignocellulose and expanding enzyme accessibility to cellulose in biomass are valid (Li et al. 2013; Chang et al. 2014; Mustafa et al. 2016a). Among which, the biological pretreatments of lignin biomass have received more and more research attention by its numerous favorable characteristics, such as cost-effectiveness, ecofriendliness and high propensity.

The degradation rate of lignin by white rot fungi (up to 30-36\%) is higher than other organisms (Chang et al. 2014; Mustafa et al. 2016a; Mishra et al. 2017). The property of selective white rot fungi to break up the lignin compound of wood in preference to cellulose and hemicelluloses can be useful. Researches have shown that the pretreatment of sawdust by selective white rot fungi can save about $30 \%$ of energy (Scott et al. 2002). In order to seek high efficiency industrial applications, large screening programs have been carried out to discover the most suitable strains, especially white rot fungi (Krogh et al. 2004; Hakala et al. 2005; Cianchetta et al. 2012). On the other hand, many researchers have studied on the catalytic mechanism of lignin degradation by the enzyme system secreted by white rot fungi. While growing on wood, white rot fungi produce extracellular laccase (Lac, EC1.10.3.2), lignin peroxidase (LiP, EC1.11.1.14) and manganese peroxidase (MnP, EC1.11.1.13) due to the large structure of lignin polymers (Chandra et al. 2007; Chen et al. 2012). And the degradation enzymes liberated lignin oxidation reaction rather than hydrolysis. Some white rot fungi produce all three of these enzymes, but most produce two or even only one (Hatakka 1994; Eggert et al. 1996a; Eggert et al. 1996b), suggesting that the presence of all three enzymes is not necessary. Of the three mentioned enzymes, laccase belongs to the copper-containing oxidase family, which can be produced by several plants, insects, fungi and bacteria. Fungal laccase with 
higher redox (0.5-0.8 v) comparing to others indicates its more application potential in lignin degradation. Numerous of studies have been conducted in laccase production by fungi fermentation.

Pseudolagarobasidium acaciicola LA1 isolated by Adak et al. produced $34444 \mathrm{U} \cdot \mathrm{gds}^{-1}$-laccase using parthenium weed (Adak et al. 2016). Zimbardi et al. optimized the fermentation conditions and improved the laccase yield of Pycnoporus sanguineus RP15 to $138.6 \mathrm{U} \cdot \mathrm{g}^{-1}$ using wheat bran and corncob (Zimbardi et al. 2016), while Trichoderma harzianum HZN10 just secreted maximum laccase activity of $65 \mathrm{U} \cdot \mathrm{g}^{-1}$ using wheat bran (Bagewadi et al. 2017). Ganoderma lucidum RCK 2011 was observed to produce maximum laccase $2989 \mathrm{U} \cdot \mathrm{g}^{-1}$ on wheat bran under optimum conditions (Sharma et al, 2018).

Simultaneously, there were significant differences in laccase activity among different strains, screening the potential producer is still relevant for customization of laccase production.

Therefore, this study aimed to screen a kind of fungus with high yield of laccase for lignin degradation, to make full use of waste agricultural straws. Then a strain with lignin degradation ability was isolated and identified as Cerrena unicolor GC.u01 by 18S rDNA gene-sequencing technology, and its related enzyme production performances under different processes were studied.

\section{Results}

\section{Screening and identification of GC.u01}

A purified strain designed as GC.u01 was selected for further study. There is high identity between the phylogenetic tree of 18S rDNA sequences from GenBank and GC.u01 constructed using the N-J method (Fig 1). According to the phylogenetic tree, GC.u01 showed high degree of genetic similarity to Cerrena unicolor (FN907915.1), which suggested that GC.u01 belongs to the same species of Cerrena unicolor, therefore it was named as Cerrena unicolor GC.u01.

As shown in Fig 2(a) and (b), the colony of Cerrena unicolor GC.u01 on PDA plate was snow-white circle, and mycelium was short and messy as catkin fluffy, with the incubation time of Cerrena unicolor GC.u01 increased in liquid medium, many small white pellets of even size grew from the original pellets. The hyphae morphology of Cerrena unicolor GC.u01 was affected significantly by culture conditions, Fig 2 (d) showed more branched and thinner hyphae than that in Fig 2 (c). It is believed that the enzyme production by fungi is correlated with hyphal tips (Krull et al. 2013). Therefore, submerged and solid-state fermentation by Cerrena unicolor GC.u01 were conducted for lignin-degrading enzymes production.

\section{Ligninolytic enzymes from Cerrena unicolor GC.u01 via submerged fermentation}

The degradation of lignin by either fungi or bacteria mainly depends on the action of a series of enzymes including Lac, LiP and MnP. (Chandra et al. 2007; Chen et al. 2012). Correspondingly, the activities of Lac, 
LiP and MnP from Cerrena unicolor GC.u01 via submerged fermentation with cornstalks as substrate were detected and shown in Table 1. The activities of these three ligninolytic enzymes were significantly different. Lac activity was generally increased firstly and then decreased. The maximum activity of Lac was $1605.28 \mathrm{U} \cdot \mathrm{L}^{-1}$ at $8^{\text {th }}$ day, following decreased sharply because of the substrate gradually exhausted. The activities of LiP and MnP were unstable, their maximum activities were $17.63 \mathrm{U} \cdot \mathrm{L}^{-1}$ at $8^{\text {th }}$ day and $28.31 \mathrm{U} \cdot \mathrm{L}^{-1}$ at $9^{\text {th }}$ day, respectively. The results showed that Cerrena unicolor $\mathrm{GC}$. $u 01$ could secrete Lac mainly to degrade lignin, and this performance is similar to Pycnoporus cinnabarinus(Eggert et al. 1996a; Eggert et al. 1996b).

The $\mathrm{pH}$ of the reaction system was maintained between 5 and 6 . The lowest $\mathrm{pH} 5.50$ was observed at $8^{\text {th }}$ day, which was the time of maximum Lac activity performed. However, the variation tendency of $\mathrm{pH}$ was generally contrary to Lac activity, indicating that $\mathrm{pH}$ had crucial influence on Lac activity.

Table 1 The activity of lignocellulase by submerged fermentation with cornstalk as substrate

\begin{tabular}{|lllll|}
\hline Time $(d)$ & $\mathrm{Lac}\left(\mathrm{U} \cdot \mathrm{L}^{-1}\right)$ & $\mathrm{LiP}\left(\mathrm{U} \cdot \mathrm{L}^{-1}\right)$ & $\mathrm{MnP}\left(\mathrm{U} \cdot \mathrm{L}^{-1}\right)$ & $\mathrm{pH}$ \\
\hline 3 & 43.06 & 10.22 & 8.77 & 5.85 \\
4 & 163.33 & 6.24 & 0.00 & 5.78 \\
5 & 76.39 & 0.00 & 0.00 & 5.84 \\
6 & 642.22 & 0.00 & 0.00 & 5.58 \\
7 & 811.85 & 0.00 & 0.00 & 5.73 \\
8 & 1605.28 & 17.63 & 0.00 & 5.50 \\
9 & 0.00 & 0.00 & 28.31 & 5.83 \\
10 & 0.00 & 0.00 & 11.54 & 5.72 \\
\hline
\end{tabular}

\section{Ligninolytic enzymes from Cerrena unicolor GC.u01 through solid-state fermentation}

Comparing to submerged fermentation, the solid-state fermentation with almost no free $\mathrm{H}_{2} \mathrm{O}$ mimics the natural environment of most fungi (Hölker et al. 2004; Barrios-Gonzalez 2012). Table 2 showed the different ligninolytic enzyme activities from Cerrena unicolor GC.u01 with rice stalks, wheat stalks and corn stalks as substrate, respectively. Lac was still the major exosenzyme, while LiP and MnP activities were only detected on certain days, which was similar with the submerged fermentation. The substrate had a significant effect on Lac activity by solid-state fermentation, and the highest Lac activities 1280.04 $\mathrm{U} \cdot \mathrm{g}^{-1}$ with rice stalks and $566.83 \mathrm{U} \cdot \mathrm{g}^{-1}$ with wheat stalks were both obtained at $10^{\text {th }}$ day and $2677.50 \mathrm{U} \cdot \mathrm{g}^{-1}$ with corn stalks at $12^{\text {th }}$ day. For LiP activity, the optimum fermentation time among different stalks were 
varied, the maximum activity $10.83 \mathrm{U} \cdot \mathrm{g}^{-1}$ with rice stalk, $8.79 \mathrm{U} \cdot \mathrm{g}^{-1}$ with wheat stalk and $24.31 \mathrm{U} \cdot \mathrm{g}^{-1}$ with corn stalk was obtained at $4^{\text {th }}$ day, $10^{\text {th }}$ day and $8^{\text {th }}$ day, respectively. However, as shown in Table 2 , Cerrena unicolor GC.u01 could not excrete MnP with wheat stalks, while $14.91 \mathrm{U} \cdot \mathrm{g}^{-1}$ with rice stalk at $10^{\text {th }}$ day and $15.22 \mathrm{U} \cdot \mathrm{g}^{-1}$ with corn stalk at $4^{\text {th }}$ day were observed, respectively. Although the activity of LiP and $\mathrm{MnP}$ were detected, they were both low and unstable comparing with that of Lac under the same conditions. Therefore, Cerrena unicolor GC.u01 is a potential strain for Lac production via solid-state fermentation and corn stalk is the suitable fermentation substrate.

Table 2 The activity of three enzymes by solid-state fermentation with different stalks

\begin{tabular}{|llll|}
\hline Time $/ \mathrm{d}$ & Rice stalks $\left(\mathrm{U} \cdot \mathrm{g}^{-1}\right)$ & Wheat stalks $\left(\mathrm{U} \cdot \mathrm{g}^{-1}\right)$ & Corn stalks $\left(\mathrm{U} \cdot \mathrm{g}^{-1}\right)$ \\
\hline 4 & 298.19 & 349.44 & \\
6 & 181.56 & 286.58 & 460.00 \\
8 & 521.56 & 493.50 & 638.00 \\
\hline 10 & 1280.04 & 566.83 & 1271.78 \\
\hline 12 & 695.08 & 368.33 & 2632.56 \\
\hline LiP & & & 2677.50 \\
4 & 10.83 & 0.00 & 0.00 \\
\hline 6 & 0.00 & 0.00 & 0.00 \\
8 & 0.00 & 0.00 & 24.31 \\
\hline 10 & 0.00 & 8.79 & 17.57 \\
\hline 12 & 0.00 & 0.00 & 0.00 \\
\hline MnP & & & 14.32 \\
\hline 4 & 13.45 & 0.00 & 0.00 \\
\hline 6 & 0.00 & 0.00 & 0.00 \\
\hline 8 & 0.00 & 0.00 & 15.00 \\
\hline 10 & 14.91 & 0.00 & \\
\hline 12 & 0.00 & 0.00 & \\
\hline
\end{tabular}

In addition, solid-liquid ratio is the most significant difference between the submerged and solid-state fermentation, the change of moisture content $(M)$ in solid-state fermentation may exert an influence on the enzyme activity. As shown in Table 3, in the solid-state fermentation, the moisture contents with 
different substrates were all around $80 \%$, and the highest moisture content was obtained at the $6^{\text {th }}$ day, which was $81.53 \%, 81.54 \%$ and $82.46 \%$, respectively. The $\mathrm{pH}$ of solid-state fermentation was basically maintained and there was no significant difference compared with that of submerged fermentation with corn stalk as substrate. Nevertheless, the $\mathrm{pH}$ values with different substrates were various, in which the $\mathrm{pH}$ of rice straw fermentation firstly decreased and then increased. The fermentation $\mathrm{pH}$ of wheat straw basically showed a trend of continuous decrease, from 5.86 at the $4^{\text {th }}$ day to 5.24 at the end. On the contrary, the fermentation $\mathrm{pH}$ of corn straw increased from 5.58 on the $8^{\text {th }}$ day to 5.91 at the $10^{\text {th }}$ day, after that, it decreased slightly but remained stable. Compared with the initial value, the final $\mathrm{pH}$ of rice straw and corn straw increased respectively, while that of wheat straw decreased.

Table 3 The moisture content and pH of solid-state fermentation by Cerrena unicolor GC.u01

\begin{tabular}{|lllllll|}
\hline Time(d) & \multicolumn{2}{l}{ Rice stalks } & \multicolumn{2}{l|}{ Wheat stalks } & \multicolumn{2}{c|}{ Corn stalks } \\
\cline { 2 - 7 } & $\mathrm{M}(\%)$ & $\mathrm{pH}$ & $\mathrm{M}(\%)$ & $\mathrm{pH}$ & $\mathrm{M}(\%)$ & $\mathrm{pH}$ \\
4 & 81.06 & 5.89 & 79.88 & 5.86 & 77.00 & 5.56 \\
\hline 6 & 81.53 & 5.45 & 81.54 & 5.41 & 82.46 & 5.56 \\
8 & 79.70 & 5.40 & 79.54 & 5.43 & 81.27 & 5.58 \\
\hline 10 & 81.12 & 5.82 & 81.11 & 5.37 & 81.24 & 5.91 \\
\hline 12 & 81.26 & 5.98 & 80.99 & 5.24 & 82.17 & 5.82 \\
\hline
\end{tabular}

\section{Lignin degradation by Cerrena unicolor GC.u01}

Although Lac, MnP and LiP are the major ligninolytic enzymes produced by most fungi, xylanase and carboxymethyl cellulase (CMCase) also play synergistic roles in the saccharification of lignocellulosic biomass. Fig 3 demonstrated the xylanase and CMCase activity with different stalks by Cerrena unicolor GC.u01 through submerged fermentation, both enzymes showed substantial increase at $18^{\text {th }}$ day compared with that of $10^{\text {th }}$ day. The maximum activities for xylanase was $23 \mathrm{U} \cdot \mathrm{mL}^{-1}$ with rice straw and CMCase was $18.5 \mathrm{U} \cdot \mathrm{mL}^{-1}$ wheat stalks, respectively, while the substrate had a significant effect on enzyme activity. The main monomer of hemicellulose is xylose, which can be degraded by xylanase. And cellulose can also be further broken down to soluble component by CMCase. Therefore, this study then analyzed the components changes of stalks to explore the synergistic effects of cell wall degradation enzymes produced by Cerrena unicolor GC.u01.

Lignin degradation is the bottlenecks of efficient utilization of biomass. The cellulose components of three stalks through solid fermentation by newly isolated fungus Cerrena unicolor GC.u01 were analyzed, and the results were shown in Table 4 and Fig 4. The lignin degradation ratios of wheat, rice 
and corn stalks were up to $24.3 \%, 34.3 \%$ and $26.2 \%$, respectively. Although the hemicellulose and cellulose contents decreased slightly, but the soluble component increased markedly.

Table 4 Chemical analyses of native and treated stalks by solid-state fermentation after 10 days

\begin{tabular}{|llllll|}
\hline Stalks & Soluble(\%) & Hemicellulose(\%) & Cellulose(\%) & Lignin(\%) & DR \\
\hline Native wheat stalks & 17.8 & 28.8 & 32.0 & 21.4 & \\
\hline Treated wheat stalks & 28.3 & 25.4 & 30.1 & 16.2 & $24.3 \%$ \\
\hline Native rice stalks & 19.4 & 26.0 & 34.5 & 20.1 & \\
\hline Treated rice stalks & 29.4 & 24.6 & 32.8 & 13.2 & $34.3 \%$ \\
\hline Native corn stalks & 21.8 & 27.5 & 31.2 & 19.5 & \\
\hline Treated corn stalks & 30.6 & 26.9 & 28.1 & 14.4 & $26.2 \%$ \\
\hline
\end{tabular}

\section{Discussion}

The degradation of lignin is usually the key obstacle to straw utilization. In the present work, a new fungus strain Cerrena unicolor GC.u01 was screened, which secrete ligninolytic enzymes. Laccase, lignin peroxidase and manganese peroxidase are the main lignin degradation enzymes (Chandra et al. 2007; Chen et al. 2012). In consequence, the activities of Lac, LiP and MnP by Cerrena unicolor GC.u01 were detected after submerged fermentation with cornstalks as substrate. The results showed that Lac secretion of Cerrena unicolor GC.u01 was mainly for lignin degradation, which was similar to the performance of Pycnoporus cinnabarinus (Eggert et al. 1996a; Eggert et al. 1996b), indicating that not all the presence of these three enzymes is required for lignin decomposition. According to the results, $\mathrm{MnP}$ was probably detectable when Lac activity was almost undetectable. White rot fungi produce enzyme systems during lignin decomposition including extracellular peroxidase (MnP and LiP) and phenol oxidase (Lac). Laccase participates in the lignin depolymerization reaction and used for oxidation of phenolic hydroxyl groups. The oxidized lignin products can be further used as substrates for MnP or LiP. Although laccase was the main lignocellulase by Cerrena unicolor GC.u01, the synergistic effect of various enzymes was still considerable.

Solid-state fermentation is in favor of Lac activity by Cerrena unicolor GC.u01 comparing to submerged fermentation both with corn stalks as substrate, which mimics the natural environment of most fungi(Hölker et al. 2004; Barrios-Gonzalez 2012), while corn stalks contains appropriate nutrients and available chemical components, and its relatively loose structure and low lignin content make it much easy for biological application. Solid-liquid ratio is the most significant difference between the submerged and solid-state fermentation. Moisture content is a key factor in solid-state fermentation that influences the laccase production, Patel et al. found that $80 \%$ moisture content was most suitable for the Lac production by Tricholoma giganteum AGHP (Patel and Gupte 2016), which was approach to our results. Noteworthily, optimum moisture level varies among different species, and the optimal water 
content for fungal laccase production by solid-state is within a narrow range of $80 \%$ - 90\% (Krishna 2005; Xin and Geng 2011; Xu et al. 2020). In addition to moisture content, mycelia morphology and energy\&mass transfer also are responsible for the differences in enzyme activity between the two fermentation processes (Xin and Geng 2011; Krull et al. 2013). However, there is no universal regularity applies to all fungi or bacteria. On the other hand, the optimum initial pH of fungal laccase activity is around 5 and kept stable at about 6 (Patel and Gupte 2016). The pH change during Lac production of Cerrena unicolor GC.u01 basically followed this characteristic.

Xylose is the main monomer of straw hemicellulose, cellulose can also be further broken down to soluble component by CMCase. Therefore, the present work then analyzed the components changes of stalks to explore the synergistic effects of lignocellulosic degradation enzymes produced by Cerrena unicolor GC.u01. The lignin degradation rate in by biology reached $15-36 \%$ owing to the secretion of MnP, Lac and LiP(Chang et al. 2014; Mustafa et al. 2016a; Mishra et al. 2017), and the maximum lignin degradation ratio was $34.3 \%$ in the present study, which was not proportional to its high enzyme activity for the following reasons: the complex structure of lignin, the complex enzymatic system involved in its degradation, and the low activities of $\mathrm{MnP}$ and Lip. However, the high laccase activity demonstrated the potential application of Cerrena unicolor GC.u01 in laccase production, Cerrena unicolor GC.u01 could collaborate with other bacteria or fungi to improve the lignin degradation rate.

As shown in Table 5, Lac activity of Cerrena unicolor GC.u01 via solid-state fermentation outclasses that of Pleurotus ostreatus(Liu et al. 2017), and is close to that of Trametes versicolor with steam-pretreated cornstalk as substrate(Adekunle et al. 2017). But fermentation methods may vary among strains. Cilerdzic et al. achieved higher Lac activity by submerged fermentation than solid-state fermentation from Ganoderma applanatum with rice bran (Cilerdzic et al. 2016), while Kaur et al. observed opposing results from Ganoderma lucidum with rice bran as substrate that $100.13 \mathrm{U} \cdot \mathrm{mL}^{-1}$ of laccase under submerged condition and $156.82 \mathrm{U} \cdot \mathrm{g}^{-1}$ under solid-state condition were obtained (Kaur et al. 2016). Mostly, solid-state fermentation has more advantages in enzymes production than submerged processes using agro-industrial residues as carbon source. Moreover, enzymes produced by solid-state fermentation are less inhibited by the substrate, temperature and pH (Holker and Lenz 2005; Barrios-Gonzalez 2012). In brief, the types of stalk and the fermentation method showed significant influence on the lignocellulosic activity of fungi. And Cerrena unicolor GC.u01 could be employed as an potential producer of the industrially enzyme laccase in solid-state fermentation bioreactor.

Table 5 Comparison of Lac activities by different strains 


\begin{tabular}{|c|c|c|c|c|}
\hline Substrate & Strain & Fermentation & $\begin{array}{l}\text { Lac } \\
\text { activity }\end{array}$ & Ref. \\
\hline Pomelo peel & Ganoderma lucidum & submerged & $\begin{array}{l}11842.13 \\
U \cdot L^{-1}\end{array}$ & $\begin{array}{l}\text { (Zhongyang et al. } \\
2012 \text { ) }\end{array}$ \\
\hline \multirow[t]{2}{*}{ Wheat straw } & $\begin{array}{l}\text { Ganoderma } \\
\text { applanatum }\end{array}$ & $\begin{array}{l}\text { submerged } \\
\text { solid-state }\end{array}$ & ${ }_{1}^{11007 \mathrm{U} \cdot \mathrm{L}^{-}}$ & $\begin{array}{l}\text { (Cilerdzic et al. } \\
\text { 2016) }\end{array}$ \\
\hline & & & $4000 \mathrm{U} \cdot \mathrm{L}^{-1}$ & \\
\hline $\begin{array}{l}\text { Steam-pretreated } \\
\text { cornstalk }\end{array}$ & Trametes versicolor & solid-state & $\begin{array}{l}2765.81 \\
U \cdot g^{-1}\end{array}$ & $\begin{array}{l}\text { (Adekunle et al. } \\
\text { 2017) }\end{array}$ \\
\hline $\begin{array}{l}\text { Ammoniated corn } \\
\text { straw }\end{array}$ & Pleurotus ostreatus & solid-state & $661 \mathrm{U} \cdot \mathrm{g}^{-1}$ & (Liu et al. 2017) \\
\hline Ricestalks & $\begin{array}{l}\text { Cerrena unicolor } \\
\text { GC.u01 }\end{array}$ & solid-state & $\begin{array}{l}1280.04 \\
U \cdot g^{-1}\end{array}$ & This study \\
\hline Cornstalks & & solid-state & $\begin{array}{l}2677.50 \\
U \cdot g^{-1}\end{array}$ & \\
\hline Cornstalks & & submerged & $\begin{array}{l}1605.28 \\
U \cdot L^{-1}\end{array}$ & \\
\hline
\end{tabular}

In summary, the end-product of laccase catalyzed oxidation is $\mathrm{H}_{2} \mathrm{O}$ without other toxic byproducts, thus laccase is considered as "green catalyst ", which brings it broad application prospects. Up to now, some achievements have been made in laccase research, but no organism can be really used in large-scale industrial production. In this work, the Cerrena unicolor GC.U01 can secrete a higher yield of laccase when using abundant corn stalk as carbon source for solid fermentation, the reaction conditions are mild, which provides a reference for the industrialized production of laccase.

\section{Conclusion}

Cerrena unicolor GC.u01 is a newly screened white rot fungus in the present work, which is capable of degrading ligninby highly activity laccase. The activity of laccase produced by this strain was influenced by the culture methods and straw types, and the lignin degradation rate was up to $34.3 \%$. More studies on conditions optimization and enzymatic properties are still necessary for application of Cerrena unicolor GC.u01 in the future $\$ to degrade agricultural waste and dyestuff, treat sewage, produce laccase as an industrial microorganism and so on.

\section{Materials And Methods}

\section{Enrichment and identification of fungus strain}


The enrichment medium for fungi PDA composed of potato $200 \mathrm{~g} \cdot \mathrm{L}^{-1}$, glucose $20 \mathrm{~g} \cdot \mathrm{L}^{-1}, \mathrm{KH}_{2} \mathrm{PO}_{4} 3 \mathrm{~g} \cdot \mathrm{L}^{-1}$, $\mathrm{MgSO}_{4} \cdot 7 \mathrm{H}_{2} \mathrm{O} 1 \mathrm{~g} \cdot \mathrm{L}^{-1}$, Vitamin $\mathrm{B} 10.02 \mathrm{~g} \cdot \mathrm{L}^{-1}$, agar $16 \mathrm{~g} \cdot \mathrm{L}^{-1}$, and the initial $\mathrm{pH}$ was nature. The medium component for fermentative enzyme production were yeast exact $2 \mathrm{~g} \cdot \mathrm{L}^{-1}, \mathrm{NaNO}_{3} 3 \mathrm{~g} \cdot \mathrm{L}^{-1}, \mathrm{KH}_{2} \mathrm{PO}_{4} 0.8 \mathrm{~g} \cdot \mathrm{L}^{-1}$, $\mathrm{K}_{2} \mathrm{HPO}_{4} 0.2 \mathrm{~g} \cdot \mathrm{L}^{-1}, \mathrm{MgSO}_{4} \cdot 7 \mathrm{H}_{2} \mathrm{O} 0.5 \mathrm{~g} \cdot \mathrm{L}^{-1}, \mathrm{MnSO}_{4} 0.034 \mathrm{~g} \cdot \mathrm{L}^{-1}, \mathrm{CuSO}_{4} \cdot 5 \mathrm{H}_{2} \mathrm{O} 0.0125 \mathrm{~g} \cdot \mathrm{L}^{-1}$ and the initial pH was 5.2 for corn stalks, 6.0 for wheat stalks and 4.5 for rice stalks.

$1 \mathrm{~g}$ solid-sample collected from birch forest was dissolved with $10 \mathrm{~mL}$ sterilized redistilled water and leached for $24 \mathrm{~h}$, leaching solution was diluted 10, 100 and 1000 times before cultured on PDA plate. When the fungi appeared, different strains were isolated, and repeated plate streaking was carried out at $28^{\circ} \mathrm{C}$ for about 3 days until purified isolates were obtained (Wang et al., 2018). The purified colony were selected for further studies.

Genomic DNA of a purified strain GC.u01 was extracted and the amplification of its 18S rDNA gene conducted with the universal primers (Forward- GTAGTCATATGCTTGTCTC; ReverseTCCGCAGGTTCACCTACGGA). The polymerase chain reaction (PCR) was performed with PCR mix kit (2xpfu Master mix, GK8008, Shanghai Generay Biotech Co., Ltd). PCR product were examined by electrophoresis with $1 \%(\mathrm{w} / \mathrm{v})$ agarose gel including $0.5 \mathrm{mg} \cdot \mathrm{mL}^{-1}$ ethidium bromide, then purified and sent to sequence (Sangon Biotech Co., Ltd). The partial 18S rDNA sequence data was submitted to GenBank database for blasting (Access number: MW150799). Several similar sequences were obtained to construct phylogenetic tree using the neighbor-joining method ( $\mathrm{N}-\mathrm{J}$ ) by MEGA 5.0(Tamura et al. 2011).

\section{Determination of cellulose components in straw}

Dried stalks collected from farmlands around Ji'nan was ground and passed through 20 meshes to obtain the powder sample. The contents of hemicellulose, cellulose and lignin were determined according to previous report (Zhang et al. 2017).

\section{Measurement of ligninolytic enzymes and data analysis}

For the submerged fermentation experiment, the purified isolation GC.u01 was inoculated into $250 \mathrm{~mL}$ conical flask with $50 \mathrm{~mL}$ liquid fermentation medium and $2.15 \mathrm{~g}$ stalks. The fermentation was carried out at $28^{\circ} \mathrm{C}$ in a rotary shaker $(150 \mathrm{rpm})$. For the solid-state fermentation experiment, the reaction system with $18 \mathrm{~mL}$ medium and $5 \mathrm{~g}$ stalks was placed under the same condition with that of submerged fermentation. Three parallel samples were set for each test.

For enzyme activity assay, culturing samples were centrifuged at $6000 \mathrm{rpm}$ for $10 \mathrm{~min}$ to remove suspended solids, then the sterile supernatant was used to detect the activities of Lac, MnP and LiP. The activities of Lac, MnP and LiP were measured by monitoring the oxidation of 2,2'-Azino-bis (3ethylbenzthiazoline-6-sulfonic acid) (ABTS) at $420 \mathrm{~nm}, 2,6$-dimethyl-phenol (2,6-DMP) at $469 \mathrm{~nm}$ and veratryl alcohol at $310 \mathrm{~nm}$, respectively (Chen et al. 2012; Kapich et al. 2004; Niladevi et al. 2008). 
The enzyme activity for submerged fermentation was calculated as Eq (1) (Mei et al., 2020), and Eq (2) was employed for the solid-fermentation.

$$
\begin{aligned}
& \mathrm{U} / \mathrm{L}=\frac{\Delta O D}{t * \varepsilon} * \frac{V t}{V s} * 10^{6} * n \\
& \mathrm{U} / \mathrm{g}=\frac{\Delta O D}{t * \varepsilon} * \frac{V t}{V s} * 10^{6} * n * 10 *(1-\mathrm{M})
\end{aligned}
$$

Where the $V t$ and $V s$ represent the total volume of measurement system $(3 \mathrm{~mL})$ and volume of supernatant added to the reaction $(0.15 \mathrm{~mL})$, respectively. The extinction coefficient $\varepsilon$ for Lac, MnP and $\mathrm{LiP}$ are $3.6 \times 10^{4}, 9.3 \times 10^{3}$ and $6.5 \times 10^{3} \mathrm{~L} \cdot \mathrm{mol}^{-1} \cdot \mathrm{cm}^{-1}$, and reaction time $t$ are 1,2 and 2 min, respectively. $\mathrm{n}=$ 1. $M$ means moisture content.

The carboxymethyl cellulase (CMCase) and xylanase activity were determined according to the reports (Wood and Bhat 1988; Tabka et al. 2006).

The lignin degradation rate was calculated by Eq (3) (Mustafa et al. 2016b).

$$
\operatorname{DR}(\%)=\left[\left(L_{0}-L_{a}\right) / L_{0}\right] \times 100
$$

Where $L_{0}$ means the lignin content in native stalks and $L_{a}$ means the lignin content in stalks after treated by isolated GC.u01.

The Origin 8 (Origin Lab, USA) was used for all statistical analysis.

\section{Declarations}

\section{Acknowledgement}

The Project Supported by the Foundation of Qilu University of Technology of Cultivating Subject for Biology and Biochemistry (No. ESIBBC202001).

\section{Ethics declarations}

All authors declare that they have no conflict of interest.

\section{References}

1.Adak, A., Tiwari, R., Singh, S., Sharma, S. and Nain, L Laccase production by a novel white-rot fungus Pseudolagarobasidium acaciicola LA1 through solid-state fermentation of parthenium biomass and its application in dyes decolorization. Waste Biomass Valori, 1427-1435. (2016). 
2.Adekunle, A.E., Zhang, C., Guo, C. and Liu, C.Z. Laccase production from Trametes versicolor in solidstate fermentation of steam-exploded pretreated cornstalk. Waste Biomass Valori8, 153-159 (2017).

3.Bagewadi, Z.K., Mulla, S.I. and Ninnekar, H.Z. Optimization of laccase production and its application in delignification of biomass. International Journal of Recycling of Organic Waste in Agriculture6, 1-15 (2017).

4.Barrios-Gonzalez, J. Solid-state fermentation: Physiology of solid medium, its molecular basis and applications. Process Biochem47, 175-185 (2012).

5.Chandra, R., Raj, A., Purohit, H.J. and Kapley, A. Characterisation and optimisation of three potential aerobic bacterial strains for kraft lignin degradation from pulp paper waste. Chemosphere67, p.839-846 (2007).

6.Chang, Y.C., Choi, D., Takamizawa, K. and Kikuchi, S. Isolation of Bacillus sp strains capable of decomposing alkali lignin and their application in combination with lactic acid bacteria for enhancing cellulase performance. Bioresour Techno/152, 429-436 (2014).

7.Chen, Y., Chai, L., Tang, C., Yang, Z., Yu, Z., Yan, S. and Zhang, H. Kraft lignin biodegradation by Novosphingobium sp. B-7 and analysis of the degradation process. Bioresour Techno/123 (2012).

8.Chen, Y., Wang, Y., Xu, Z., Liu, Y. and Duan, H. Enhanced humification of maize straw and canola residue during composting by inoculating Phanerochaete chrysosporium in the cooling period. Bioresour Techno/293 (2019).

9.Cianchetta, S., Galletti, S., Burzi, P.L. and Cerato, C. Hydrolytic potential of Trichoderma sp strains evaluated by microplate-based screening followed by switchgrass saccharification. Enzyme Microb Tech50, 304-310 (2012).

10.Cilerdzic, J., Stajic, M. and Vukojevic, J. Degradation of wheat straw and oak sawdust by Ganoderma applanatum. Int Biodeter Biodegr114, 39-44 (2016).

11.Eggert, C., Temp, U., Dean, J.F.D. and Eriksson, K.E.L. A fungal metabolite mediates degradation of nonphenolic lignin structures and synthetic lignin by laccase. Febs Lett391, 144-148 (1996a).

12.Eggert, C., Temp, U. and Eriksson, K.E.L. The ligninolytic system of the white rot fungus Pycnoporus cinnabarinus: Purification and characterization of the laccase. Appl Environ Microb62, 1151-1158 (1996b).

13.Hakala, T.K., Lundell, T., Galkin, S., Maijala, P., Kalkkinen, N. and Hatakka, A. Manganese peroxidases, laccases and oxalic acid from the selective white-rot fungus Physisporinus rivulosus grown on spruce wood chips. Enzyme \& Microbial Technology36, 461-468 (2005). 
14. Hatakka, A. Lignin-modifying enzymes from selected white-rot fungi - production and role in lignin degradation. Fems Microbiol Rev13, 125-135 (1994).

15.Hölker, U., Höfer, M. and Lenz, J. Biotechnological advantages of laboratory-scale solid-state fermentation with fungi. Appl Microbiol Biot64, 175-186 (2004).

16.Hölker, U. and Lenz, J. Solid-state fermentation - are there any biotechnological advantages? Curr Opin Microbio/8, 301-306 (2005).

17.Kapich, A.N., Prior, B.A., Botha, A., Galkin, S., Lundell, T. and Hatakka, A. Effect of lignocellulosecontaining substrates on production of ligninolytic peroxidases in submerged cultures of Phanerochaete chrysosporium ME-446. Enzyme Microb Tech34, 187-195 (2004).

18.Kaur, H., Kapoor, S. and Kaur, G. Application of ligninolytic potentials of a white-rot fungus Ganoderma lucidum for degradation of lindane. Environ Monit Assess188 (2016).

19.Krishna, C. Solid-state fermentation systems - An overview. Crit Rev Biotechno/25, 1-30 (2005).

20.Krogh, K.B.R., Morkeberg, A., Jorgensen, H., Frisvad, J.C. and Olsson, L. Screening genus Penicillium for producers of cellulolytic and xylanolytic enzymes. Appl Biochem Biotech113, 389-401 (2004).

21.Krull, R., Wucherpfennig, T., Esfandabadi, M.E., Walisko, R., Melzer, G., Hempel, D.C., Kampen, I., Kwade, A. and Wittmann, C. Characterization and control of fungal morphology for improved production performance in biotechnology. J Biotechno/163, 112-123 (2013).

22.Li, J., Lin, J., Xiao, W., Gong, Y., Wang, M., Zhou, P. and Liu, Z. Solvent extraction of antioxidants from steam exploded sugarcane bagasse and enzymatic convertibility of the solid fraction. Bioresour Techno/130, 8-15 (2013).

23.Liu, J., Liu, B., Zhan, L., Wang, P., Ju, M. and Wu, W. Solid-state fermentation of ammoniated corn straw to animal feed by Pleurotus ostreatus PI-5. Bioresources12 (2017).

24.Mathew, G.M., Mathew, D.C., Lo, S.C., Alexios, G.M. and Huang, C.C. Synergistic collaboration of gut symbionts in Odontotermes formosanus for lignocellulosic degradation and bio-hydrogen production. Bioresour Techno/145, 337-344 (2013) .

25.Mei, J., Shen, X., Gang, L., Xu, H., and Sheng, L. A novel lignin degradation bacteria - Bacillus amyloliquefaciens SL- 7 used to degrade straw lignin efficiently. Bioresour Techno/ 310:123445 (2020).

26.Mei, Y., Zhang, S., Wang, H., Jing, S. and Pang, S. Low-temperature deoxidization of lignin and its impact on liquid products from pyrolysis. Energ Fue/34, 3422-3428 (2020).

27.Mishra, V., Jana, A.K., Jana, M.M. and Gupta, A. Enhancement in multiple lignolytic enzymes production for optimized lignin degradation and selectivity in fungal pretreatment of sweet sorghum 
bagasse. Bioresour Techno/236, 49-59 (2017).

28.Mustafa, A.M., Poulsen, T.G. and Sheng, K.C. Fungal pretreatment of rice straw with Pleurotus ostreatus and Trichoderma reesei to enhance methane production under solid-state anaerobic digestion. Appl Energ180, 661-671 (2016a).

29.Mustafa, A.M., Poulsen, T.G., Xia, Y. and Sheng, K. Combinations of fungal and milling pretreatments for enhancing rice straw biogas production during solid-state anaerobic digestion. Bioresour Technol, S0960852416315334 (2016b).

30.Niladevi, K.N., Jacob, N. and Prema, P. Evidence for a halotolerant-alkaline laccase in Streptomyces psammoticus: Purification and characterization. Process Biochemistry43, 654-660 (2008).

31.Patel, H. and Gupte, A. Optimization of different culture conditions for enhanced laccase production and its purification from Tricholoma giganteum AGHP. Bioresources \& Bioprocessing3, 11 (2016).

32.Scott, G.M., Akhtar, M., Swaney, R.E. and Houtman, C.J. Recent developments in biopulping technology at Madison, WI. Progress in Biotechnology21, 61-71 (2002).

33.Sharma A, Jain K K, Srivastava A, Shrivastava, B. , Thakur, V. V. and Jain, R. K. Potential of in situ SSF laccase produced from Ganoderma lucidum RCK 2011 in biobleaching of paper pulp. Bioprocess and Biosystems Engineering42, 367-377 (2018).

34.Tabka, M.G., HerpoL-Gimbert, I., Monod, F., Asther, M. and Sigoillot, J.C. Enzymatic saccharification of wheat straw for bioethanol production by a combined cellulase xylanase and feruloyl esterase treatment. Enzyme \& Microbial Technology39, 897-902 (2006) .

35.Tamura, K., Peterson, D., Peterson, N., Stecher, G., Nei, M. and Kumar, S. MEGA5: molecular evolutionary genetics analysis using maximum likelihood, evolutionary distance, and maximum parsimony methods. Mol Biol Evol28, 2731-2739 (2011) .

36.Wood, T.M. and Bhat, K.M. Methods for measuring cellulase activities. Methods Enzymo/160, 87-112 (1988).

37.Wang, Y., Luo, J., Shan, S., Jiang, J., Quan, X., Songquan, W.U., Huang, S.Isolation and identification of root rot fungus of Astragalus membranaceus. Agricultural Biotechnology, 7, 250-253 (2018) .

38.Xin, F.X. and Geng, A.L. Utilization of horticultural waste for laccase production by Trametes versicolor under solid-state fermentation. Appl Biochem Biotech163, 235-246 (2011).

39.Xu, L., Sun, K., Wang, F., Zhao, L.T., Hu, J.H., Ma, H.L. and Ding, Z.Y. Laccase production by Trametes versicolor in solid-state fermentation using tea residues as substrate and its application in dye decolorization. J Environ Manage270 (2020). 
40.Zhang, Y., Li, Q., Wang, X., Yang, H. and Guo, L. Enhanced biohydrogen production from cornstalk through a two-step fermentation: Dark fermentation and photofermentation. Int J Energ Res 41 (2017).

41.Zimbardi, A.L.R.L., Camargo, P.F., Carli, S., Neto, S.A., Meleiro, L.P., Rosa, J.C., De Andrade, A.R., Jorge, J.A. and Furriel, R.P.M. A high redox potential laccase from Pycnoporus sanguineus RP15: Potential application for dye decolorization. Int J Mol Sci17 (2016).

\section{Figures}

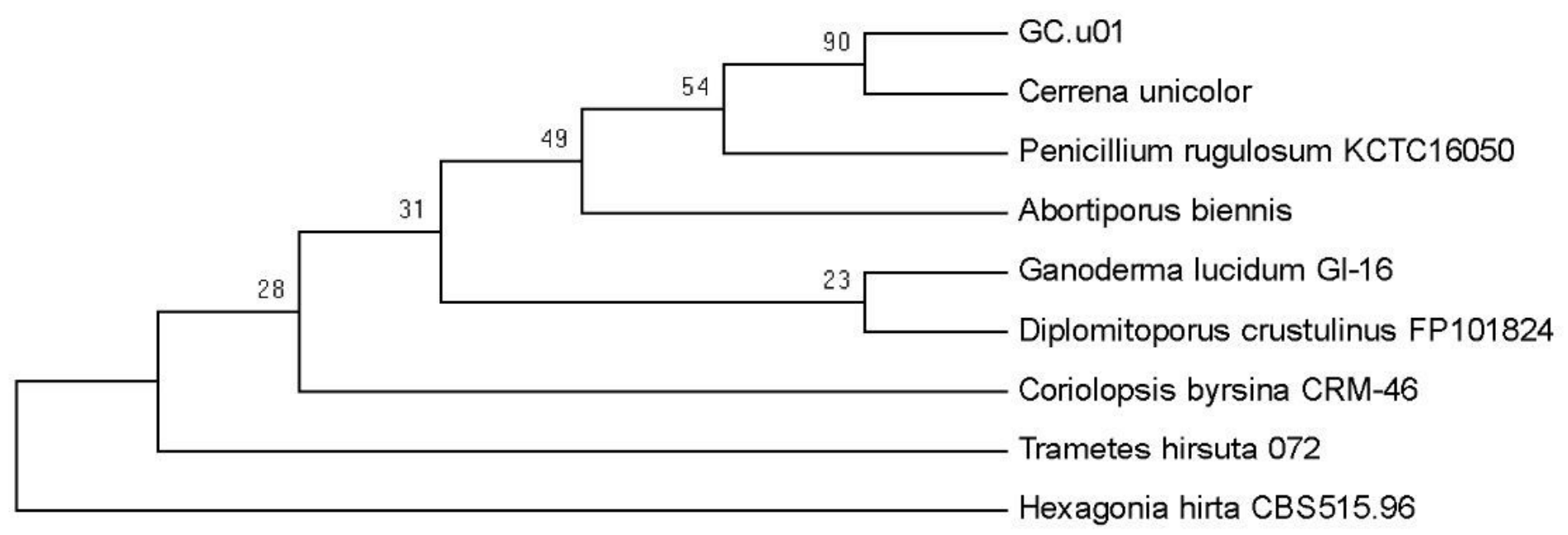

\section{Figure 1}

Phylogenetic tree of $18 \mathrm{~S}$ rDNA sequences constructed with the N-J method

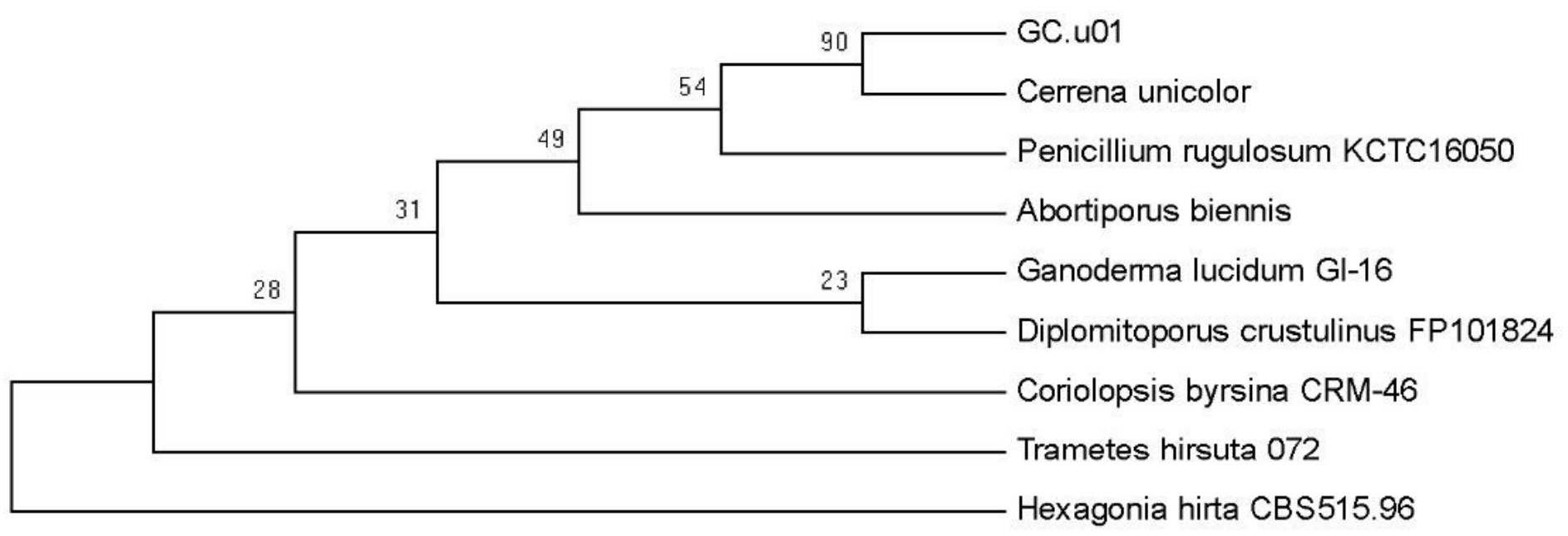

\section{Figure 1}

Phylogenetic tree of $18 \mathrm{~S}$ rDNA sequences constructed with the N-J method 


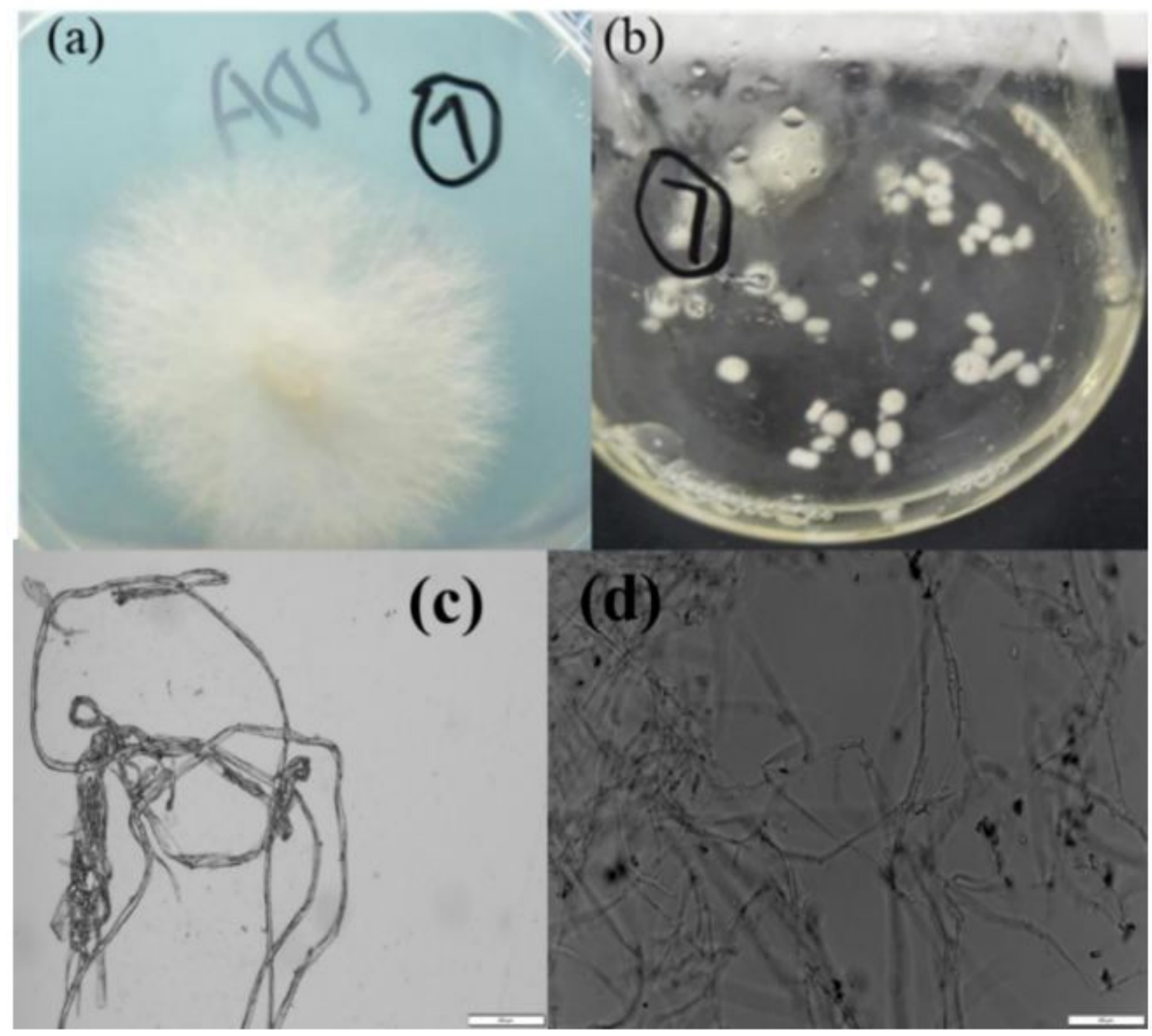

Figure 2

Morphological characteristics of Cerrena unicolor GC.u01: (a) colony on PDA plate; (b) pellets in liquid medium; (c) and (d) hyphae morphology of colony and pellets magnified 100 times 


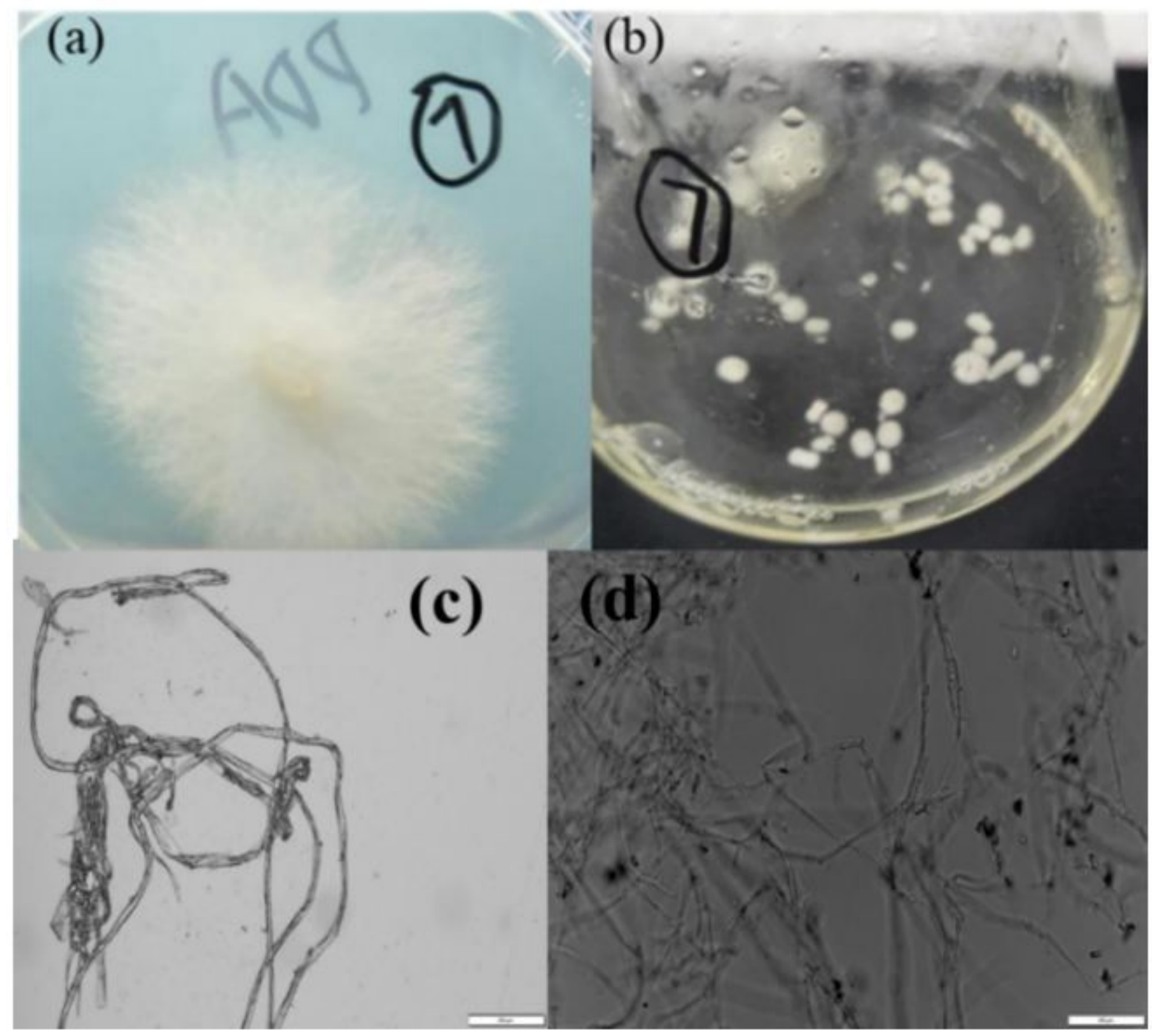

Figure 2

Morphological characteristics of Cerrena unicolor GC.u01: (a) colony on PDA plate; (b) pellets in liquid medium; (c) and (d) hyphae morphology of colony and pellets magnified 100 times 

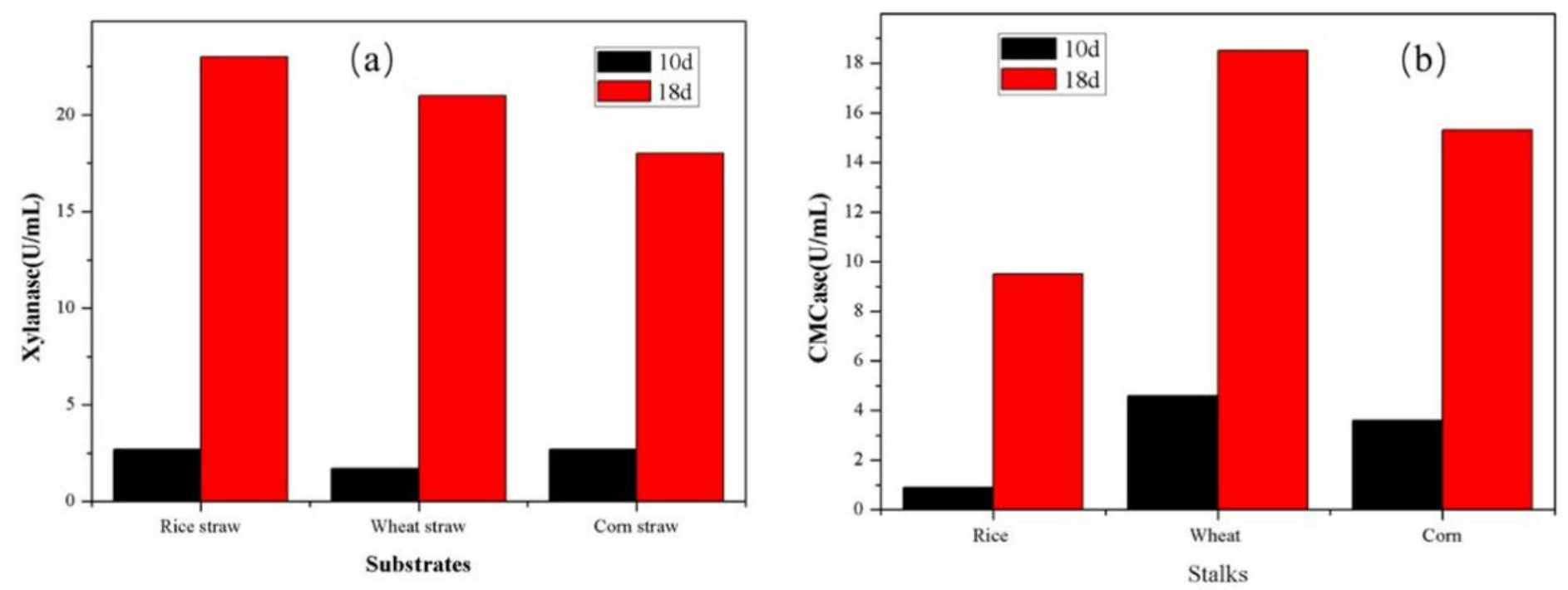

Figure 3

The xylanase (a) and CMCase (b) activity with different stalks
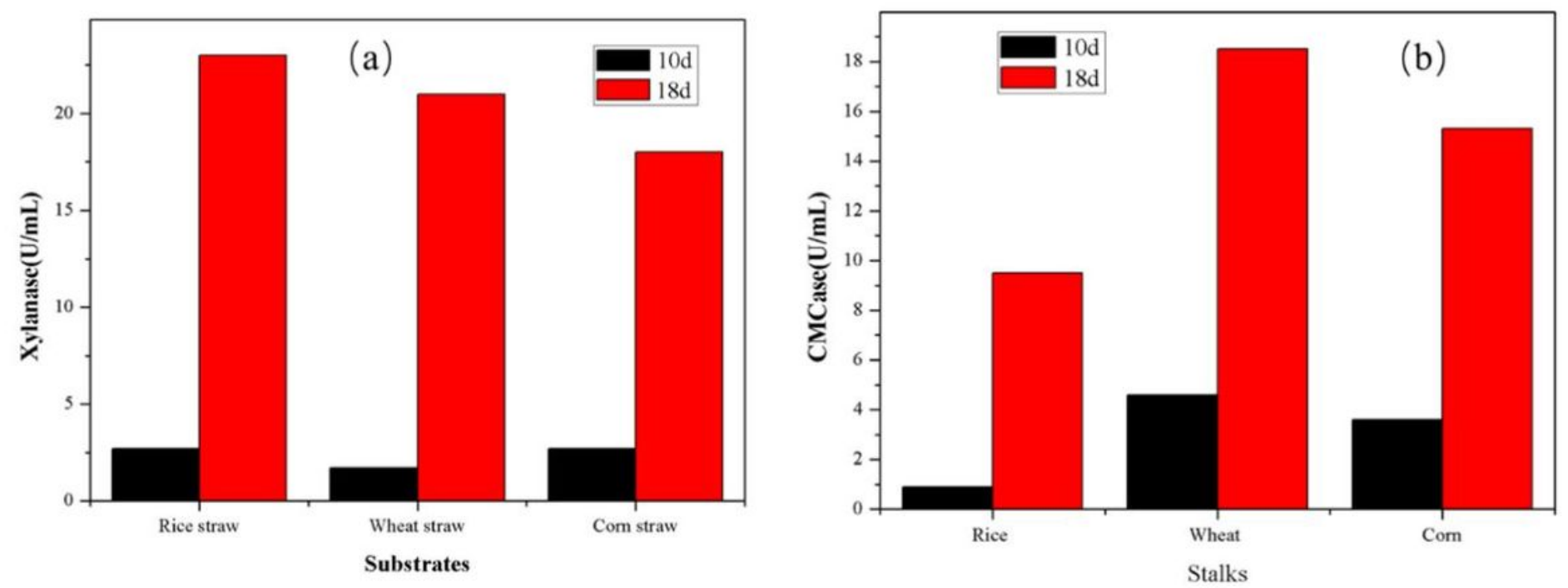

Figure 3

The xylanase (a) and CMCase (b) activity with different stalks 


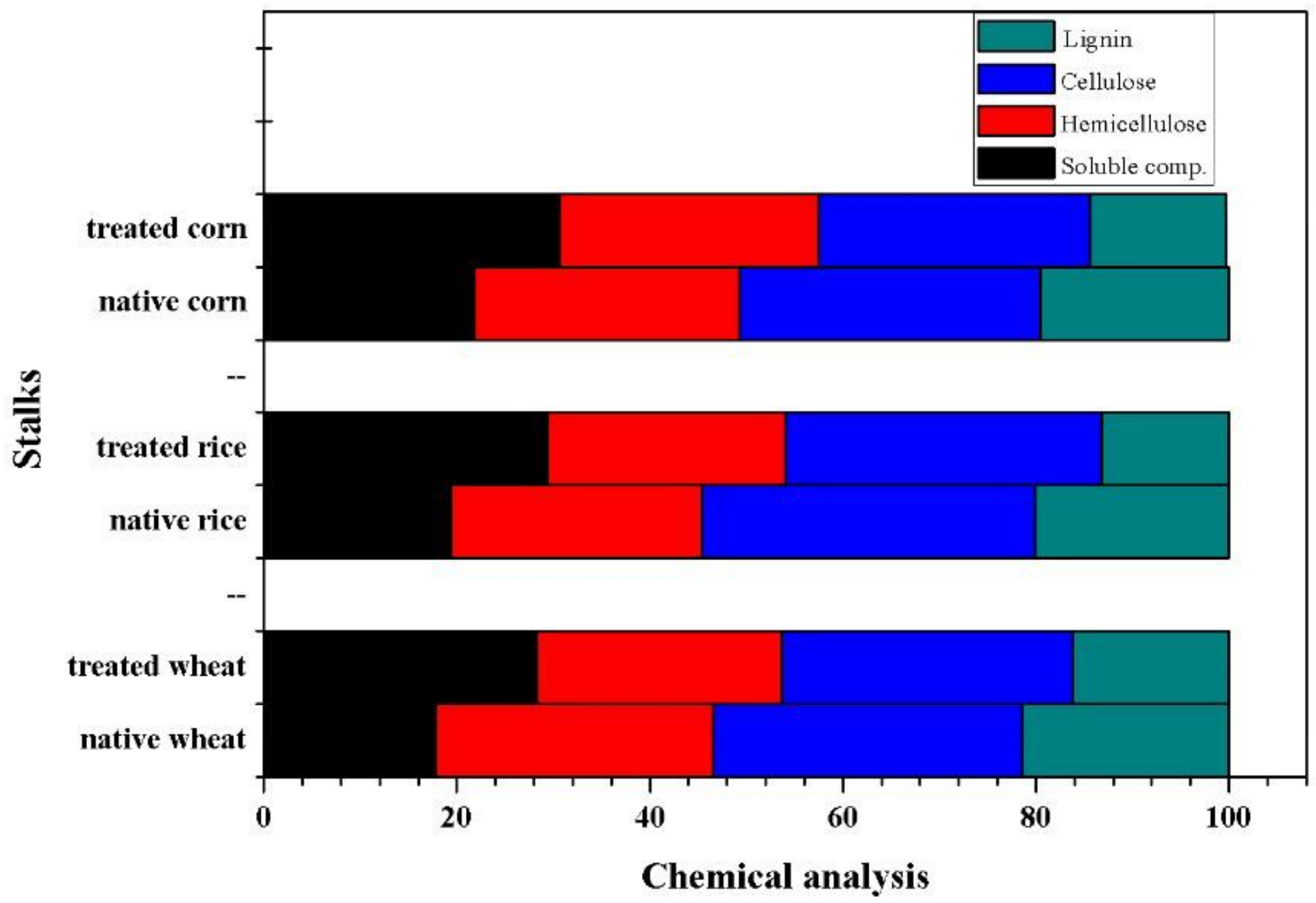

Figure 4

Component analysis of three stalks before and after the solid-state fermentation 


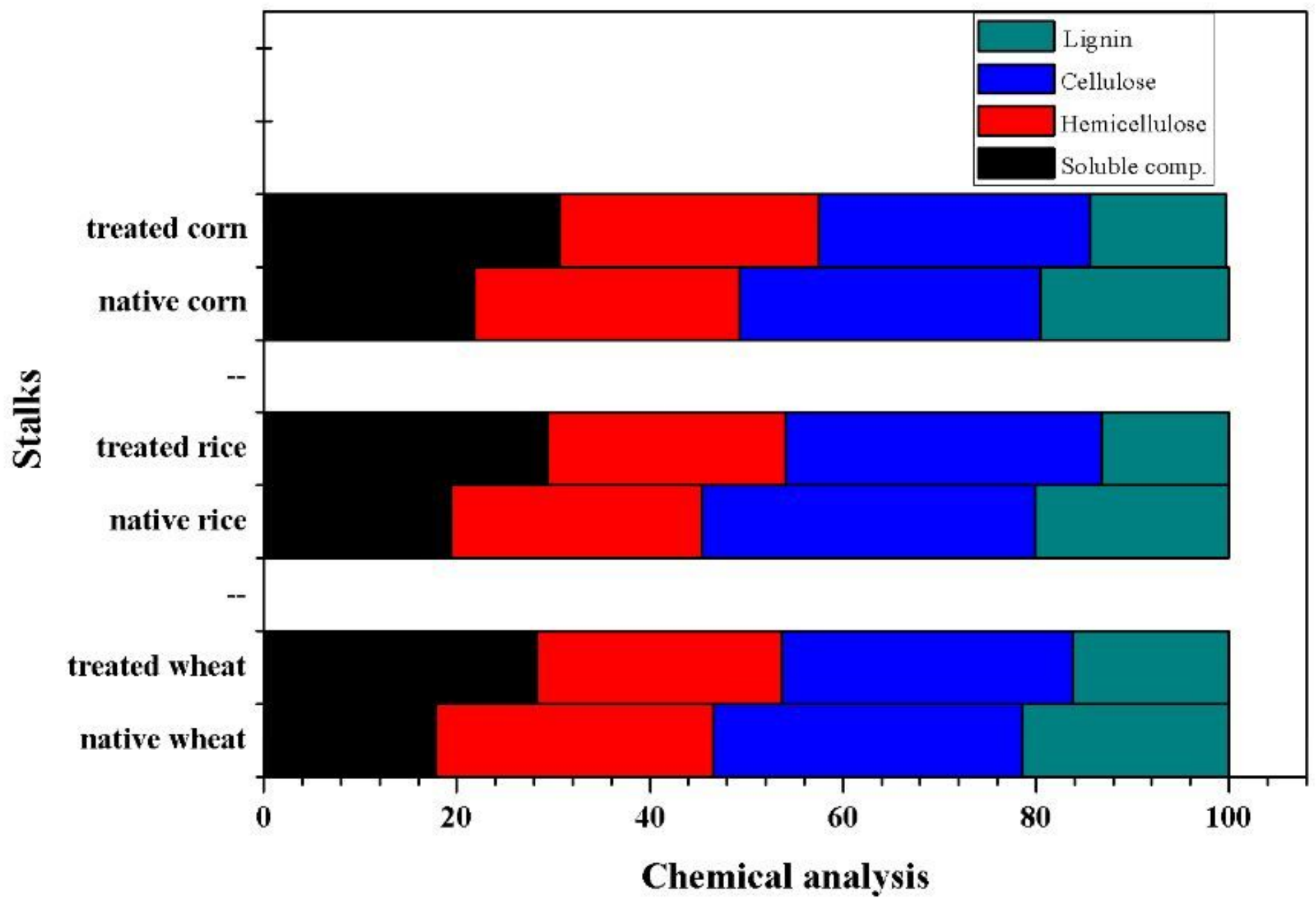

Figure 4

Component analysis of three stalks before and after the solid-state fermentation 